J. Clin. Chem. Clin. Biochem.

Vol. 17, 1979, pp. 633-638

\title{
Evaluation of a New Diagnostic Kit for the Enzymatic Determination of Creatinine
}

\author{
By A. Lanser, B. G. Blijenberg and B. Leijnse \\ Department of Clinical Chemistry, University Hospital, and Department of Chemical Pathology, Erasmus University,
Rotterdam
}

(Received January 16/May 21, 1979)

\begin{abstract}
Summary: We have evaluated a new diagnostic kit for the enzymatic determination of creatinine in serum, plasma and urine. The method was found to be linear up to $1000 \mu \mathrm{mol} / \mathrm{l}$. Within-run precision had a coefficient of variation of 3.1-5.6\% for normal to slightly elevated values and of $2.3-3.3 \%$ for values of about $320 \mu \mathrm{mol} / 1$. Day-to-day precision was found to be 7.8 and $5.7 \%$ for values of 94 and $141 \mu \mathrm{mol} / 1$, respectively. Mean analytic recovery was $98 \%$. Bilirubin and hemoglobin did not interfere in concentrations up to 490 and $240 \mu \mathrm{mol} / 1$, respectively. The influence of lipids was studied. Correlation studies were done with two other methods, the Technicon SMA 12/60 method and the Dutch standard manual method.
\end{abstract}

\section{Evaluation eines neuen diagnostischen Reagenzbesteckes für die enzymatische Bestimmung von Kreatinin.}

Zusammenfassung: Ein neues diagnostisches Reagenzbesteck für die enzymatische Bestimmung von Kreatinin in Serum, Plasma und Harn wurde geprüft. Die Methode mißt linear bis $1000 \mu \mathrm{mol} / 1$. Für die Präzision in der Serie wurde für normale bis leicht erhöhte Werte ein Variationskoeffizient (VK) von 3,1-5,6\%, für Werte um $320 \mu \mathrm{mol} / 1$ ein VK von 2,3-3,3\% errechnet. Die Präzision von Tag zu Tag ergab einen VK von 7,8\% für $94 \mu \mathrm{mol} / 1$ und einen VK von 5,7\% für $141 \mu \mathrm{mol} / 1$. Die Wiederfindung betrug im Mittel $98 \%$. Bilirubin (bis $490 \mu \mathrm{mol} / \mathrm{l}$ ) und Hämoglobin (bis $240 \mu \mathrm{mol} / \mathrm{l}$ ) störten die Bestimmung nicht. Der Einfluß von Lipiden wurde untersucht. Untersuchungen der Korrelation mit der Technicon SMA 12/60-Methode und der Niederländischen manuellen Standardmethode wurden durchgeführt.

\section{Introduction}

Many methods have been published for the determination of creatinine in serum or plasma and urine. Most of these methods are based on the reaction of creatinine with an alkaline picrate reagent, the Jaffe reaction (1). Both endpoint and kinetic methods have been described. Unfortunately, neither of these methods is specific for creatinine. Furthermore, the Jaffe reaction is disturbed by many common drugs and metabolites $(2,3)$. Since enzymatic methods are known for their specificity, some investigators have been working on an enzymatic creatinine determination $(4,5)$. The diagnostic kit "Creatinine Enzymatic" from Boehringer Mannheim $\mathrm{GmbH}$ is based on the work of Wahlefeld et al. (4). In this test method, creatinine is hydrolyzed by the enzyme creatinine-amidohydrolase (EC 3.5.2.10). For each mol of creatinine hydrolyzed, one mol of $\mathrm{NAD}^{+}$is formed, according to the following reaction sequence:

$$
\begin{array}{ll}
\text { Creatinine }+\mathrm{H}_{2} \mathrm{O} & \frac{\text { Creatinine-amidohydrolase }}{\text { EC 3.5.2.10 }} \text { Creatine } \\
\text { Creatine + ATP } & \frac{\text { Creatine Kinase }}{\text { EC 2.7.3.2 }} \text { Creatine-P + ADP } \\
\text { ADP + PEP } & \frac{\text { Pyruvate Kinase Pyruvate + ATP }}{\text { EC 2.7.1.40 }} \\
\text { Pyruväte + NADH }+\mathrm{H}^{+ \text {Lactate Dehydrogenase }} & \text { EC-lactate }+ \\
& \text { NA.1.1.27 }
\end{array}
$$

Since normal serum also contains substances that can cause conversion of NADH to $\mathrm{NAD}^{+}$(e.g. pyruvate), a serum blank is necessary. 
Here, we report our experience with the Boehringer test kit, with regard to linearity, precision, recovery and interference of bilirubin, hemoglobin and lipids. Furthermore, we checked if commercial sera could be used for quality control purposes. Finally, we compared this method with two other methods, the Technicon SMA 12/60 method, which is in routine use in our laboratory, and the manual Dutch standard method.

\section{Materials and Methods}

\section{Equipment}

All absorbance measurements were pèrformed at $340 \mathrm{~nm}$ on a Beckman model 25 spectrophotometer. The instrument is checked regularly with respect to wavelength (holmium) and absorbance (cobalt sulphate) according to Rand (6). For pipetting we used Eppendorf pipets with Eppendorf disposable tips.

\section{Creatinine}

Creatinine was purchased from E. Merck AG (cat. no. 5208).

\section{Bilirubin}

Bilirubin p.a. was obtained from E. Merck AG (cat.no. 24519). A stock solution of bilirubin ( $5000 \mu \mathrm{mol} / \mathrm{l})$ was prepared according to Dybkaer \& Hertz (7) and small volumes of this solution were added to serum samples. Final bilirubin concentrations in the serum samples were checked on our DuPont Automatic Clinical Analyzer (aca).

\section{Hemoglobin}

A red cell hemolysate was prepared according to van Assendelft (8). Small volumes of this hemolysate were added to serum samples. Final hemoglobin concentrations were checked with the method of Crosby \& Furth (9).

\section{Technicon SMA 12/60 method}

Creatinine determinations were performed according to the normal SMA $12 / 60$ procedure. The creatinine tubing system of our SMA 12/60 has been slightly modified by IJpma et al. (10).

\section{Manual methods}

For serum and urine determinations we used the methods of the Dutch Standardization Committee on Clinical Chemistry. The serum procedure is highly comparable to the method of Knoll \& Wisser (11). All samples were analyzed in duplicate.

\section{Enzymatic method}

The enzymatic method (Boehringer Mannheim Test Combination Creatinine Enzymatic, cat. no. 166413) was applied according to the manufacturers' instructions for measurement at $340 \mathrm{~nm}$. We halved all volumes mentioned in the instruction sheet. All samples were analyzed in duplicate.

\section{Results}

Six different human serum pools were used for precision studies. Samples used for day-to-day precision studies were kept at $-20^{\circ} \mathrm{C}$ until needed. The results for the enzymatic method are given in table 1.

For comparison, samples 2 and 4 from table 1 gave within-run coefficients of variation of 1.1 and $0.9 \%$, respectively on our SMA $12 / 60(n=20)$. The manual method had within-run coefficients of variation of 4.0 and $1.1 \%$ for values of 86 and $538 \mu \mathrm{mol} / 1$ respectively $(n=10)$.

\section{Linearity}

Linearity was checked with primary standards. The enzymatic method was linear up to $1000 \mu \mathrm{mol} / \mathrm{l}$, as is shown in figure 1.

Since linearity is limited by the available amount of NADH in the reaction mixture and since serum itself contains substances that can convert NADH to $\mathrm{NAD}^{+}$, the linearity limit in serum may not be that high. In the instruction sheet an upper limit of $712 \mu \mathrm{mol} / \mathrm{l}$ is mentioned. In all further experiments we performed, every sample with a creatinine concentration exceeding that limit was diluted with saline.

\section{Recovery}

To six different human sera with creatinine concentrations ranging from 66 to $224 \mu \mathrm{mol} / 1$, small volumes of an aqueous creatinine solution $(10 \mathrm{mmol} / \mathrm{l})$ were added. Table 2 shows the results of these recovery experiments. Mean analytic recovery was found to be $98 \%$.

Tab. 1. Results of precision studies with the enzymatic method, obtained with six different serum pools of human origin.

\begin{tabular}{|c|c|c|c|c|c|c|c|c|c|}
\hline \multicolumn{4}{|c|}{ Within-run precision } & \multirow{2}{*}{$\begin{array}{l}n \\
\mathrm{n}\end{array}$} & \multicolumn{4}{|c|}{ Day-to-day precision } & \multirow[b]{2}{*}{$\cdot \mathbf{n}$} \\
\hline Sample no. & $\begin{array}{l}\text { Average } \\
(\mu \mathrm{mol} / \mathrm{l})\end{array}$ & $\begin{array}{l}\text { S.D. } \\
(\mu \mathrm{mol} / \mathrm{l})\end{array}$ & $\begin{array}{l}\text { C.V. } \\
(\%)\end{array}$ & & Sample no. & $\begin{array}{l}\text { Average } \\
(\mu \mathrm{mol} / \mathrm{l})\end{array}$ & $\begin{array}{l}\text { S.D. } \\
(\mu \mathrm{mol} / \mathrm{l})\end{array}$ & $\begin{array}{l}\text { C.V. } \\
\text { (\%) }\end{array}$ & \\
\hline $\begin{array}{l}1 \\
2 \\
3 \\
4\end{array}$ & $\begin{array}{r}85 \\
119 \\
321 \\
\cdot 322\end{array}$ & $\begin{array}{r}2.7 \\
6.7 \\
7.5 \\
10.6\end{array}$ & $\begin{array}{l}3.1 \\
5.6 \\
2.3 \\
3.3\end{array}$ & $\begin{array}{l}22 \\
20 \\
22 \\
20\end{array}$ & $\begin{array}{l}5 \\
6\end{array}$ & $\begin{array}{r}94 \\
140\end{array}$ & $\begin{array}{l}7.3 \\
7.9\end{array}$ & $\begin{array}{l}7.8 \\
5.7\end{array}$ & $\begin{array}{l}10 \\
11\end{array}$ \\
\hline
\end{tabular}




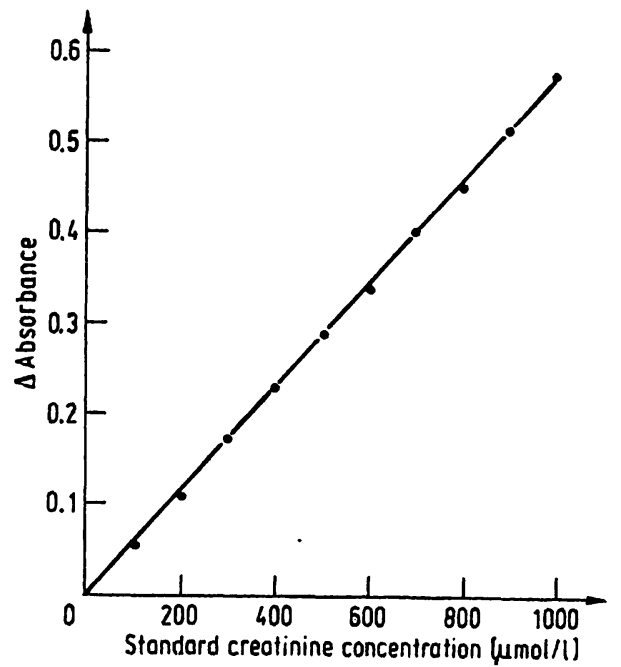

Fig. 1. Linearity of the enzymatic method. Curve constructed with aqueous standards.

Tab. 2. Results of recovery studies with the enzymatic method

\begin{tabular}{llllc}
\hline Sample no. & $\begin{array}{l}\text { Initial } \\
\text { value } \\
(\mu \mathrm{mol} / \mathrm{l})\end{array}$ & $\begin{array}{l}\text { Added crea- } \\
\text { tinine } \\
(\mu \mathrm{mol} / \mathrm{l})\end{array}$ & $\begin{array}{l}\text { Final } \\
\text { value } \\
(\mu \mathrm{mol} / \mathrm{l})\end{array}$ & $\begin{array}{l}\text { Recovery } \\
(\%)\end{array}$ \\
\hline 1. & 66 & 91 & 156 & 99 \\
2. & 68 & 91 & 152 & 92 \\
3. & 108 & 91 & 197 & 98 \\
4. & 224 & 91 & 312 & 97 \\
5. & 54 & 91 & 150 & 105 \\
5. & 54 & 180 & 227 & 96 \\
5. & 54 & 268 & 325 & 101 \\
5. & 54 & 353 & 392 & 96 \\
6. & 94 & 180 & 269 & 96 \\
6. & 94 & 268 & 367 & 101 \\
\hline
\end{tabular}

\section{Interferences}

Bilirubin and hemoglobin were added to different serum pools (see materials and methods). The effects of increasing concentrations of bilirubin and hemoglobin are summarized in table 3.

The influence of lipemia was checked with 22 lipemic sera. The degree of lipemia, judged qualitatively, ranged from slightly to severely lipemic. In general; lipemic samples can cause measuring problems because of the turbidity of the serum-reagent mixture. 19 of the 22 lipemic sera, with triglyceride concentrations in the range of 2.7 to $7.5 \mathrm{mmol} / 1$ and cholesterol concentrations up to $11 \mathrm{mmol} / 1$, could be measured without problems. The other three lipemic sera had triglyceride concentrations of 9.0, 32.6 and $36.0 \mathrm{mmol} / \mathrm{l}$ and could not be measured without predilution of the samples. Both last mentioned sera had to be diluted 5 times. The 19 aforementioned sera are represented in figure 2 .
Tab. 3. Effects of increasing concentrations of bilirubin and hemoglobin on the measured creatinine concentration.

\begin{tabular}{|c|c|c|c|c|}
\hline $\begin{array}{l}\text { Serum A } \\
\text { CreatinineBilirubin } \\
(\mu \mathrm{mol} / \mathrm{l}) \quad(\mu \mathrm{mol} / \mathrm{l})\end{array}$ & $\begin{array}{l}\text { Serum B } \\
\text { Creatinine } \\
\text { (umol/1) }\end{array}$ & $\begin{array}{c}\text { eBilirubin } \\
(\mu \mathrm{mol} / \mathrm{l})\end{array}$ & $\begin{array}{l}\text { Serum C } \\
\text { Creatinine } \\
\text { (umol/1) }\end{array}$ & $\begin{array}{l}\text { eHemoglobin } \\
(\mu \mathrm{mol} / \mathrm{l})\end{array}$ \\
\hline $\begin{array}{lr}321 \pm 15 * 18 \\
310 & 81 \\
325 & 122 \\
317 & 175 \\
324 & 226 \\
321 & 275 \\
329 & 297 \\
321 & 361 \\
321 & 406 \\
320 & 462 \\
321 & 494\end{array}$ & $\begin{array}{l}88 \pm 5^{*} \\
87 \\
90 \\
87 \\
92 \\
90 \\
90 \\
91 \\
92 \\
91 \\
89\end{array}$ & $\begin{array}{r}17 \\
60 \\
97 \\
146 \\
197 \\
248 \\
284 \\
318 \\
321 \\
359 \\
468\end{array}$ & $\begin{array}{l}313 \pm 15 * \\
319 \\
316 \\
319 \\
325 \\
312 \\
309 \\
313 \\
310 \\
283 \\
273 \\
245\end{array}$ & $\begin{array}{r}10 \\
34 \\
49 \\
81 \\
99 \\
148 \\
174 \\
213 \\
244 \\
286 \\
312 \\
380\end{array}$ \\
\hline
\end{tabular}

* Average \pm 2 S.D. for the original serum.

Tab. 4. Influence of anticoagulants in common concentrations on the measured creatinine concentration.

\begin{tabular}{|c|c|c|}
\hline Anticoagulant & Concentration & $\begin{array}{l}\text { Creatinine } \\
(\mu \mathrm{mol} / \mathrm{l})\end{array}$ \\
\hline $\begin{array}{l}\text { no } \\
\text { Sodium fluoride } \\
\text { Sodium oxalate } \\
\text { Sodium oxalate } \\
\text { Heparin-lithium* } \\
\text { Potassium EDTA* } \\
\text { Sodium fluoride/ } \\
\quad \text { Potassium oxalate* } \\
\text { Sodium citrate }\end{array}$ & $\begin{array}{c}- \\
1 \mathrm{~g} / 1 \\
1 \mathrm{~g} / 1 \\
2 \mathrm{~g} / 1 \\
7.5 \mathrm{kU} / 1 \\
3 \mathrm{~g} / 1 \\
1 \mathrm{~g} / 1 \\
3 \mathrm{~g} / 1 \\
6.2 \mathrm{~g} / 1\end{array}$ & $\begin{array}{l}313 \pm 15 \\
320 \\
295 \\
235 \\
317 \\
315 \\
193 \\
314\end{array}$ \\
\hline
\end{tabular}

* Commercial tubes

To check the interference of anticoagulants, we added different anticoagulants to a serum pool in concentrations commonly used. The results are represented in table 4.

A commonly used preservative, sodium azide, in a concentration of $1 \mathrm{~g} / \mathrm{l}$, was shown to have no effect on the measured creatinine concentration.

\section{Split-sample comparisons}

We compared the enzymatic method with two other methods, the SMA 12/60 method and the Dutch standard manual method (see materials and methods).

Serum samples were analyzed in duplicate by the three aforementioned methods, urine samples were analyzed in duplicate by the three aforementioned methods, urine samples were analyzed with the enzymatic and manual method only.

Figures 2,3 and 4 show the results of these comparisons. 


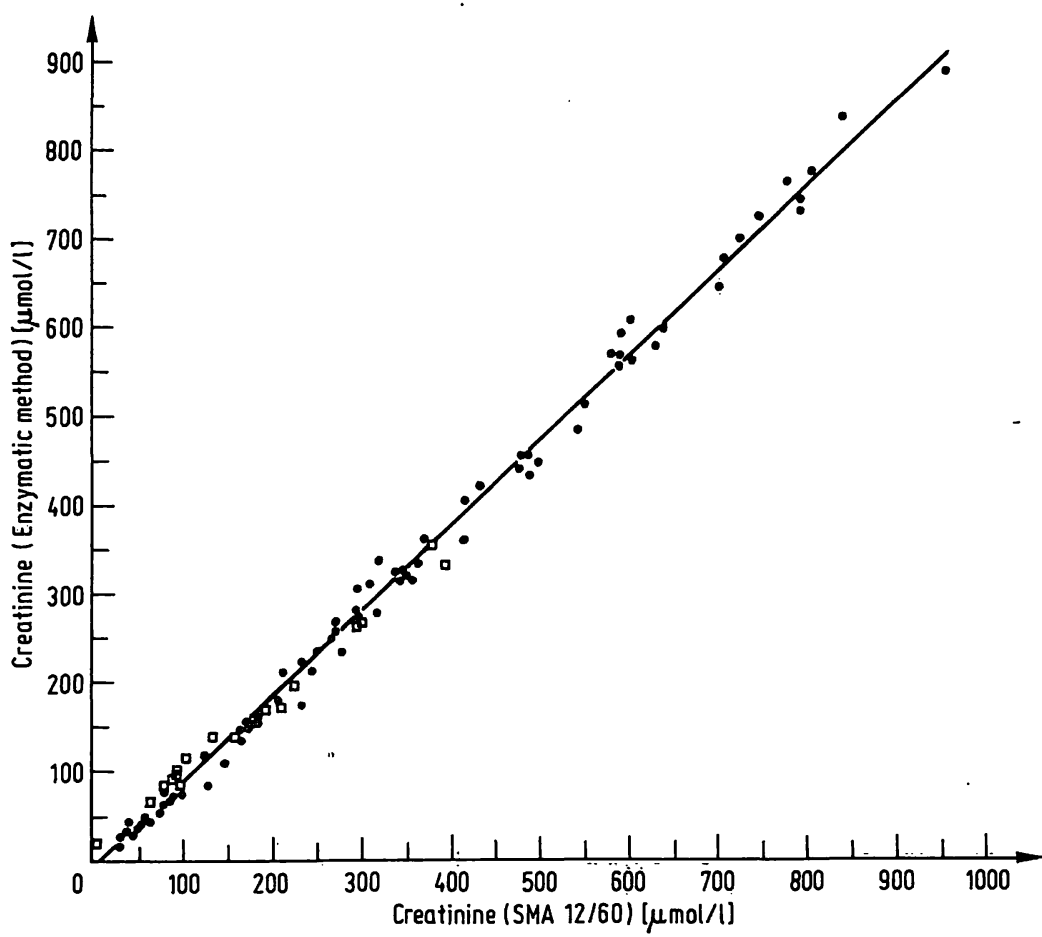

Fig. 2. Split-sample comparison between the enzymatic method (y-axis) and the SMA $12 / 60$ method (x-axis). Straight line represents the regression line (equation: $y=-12.227+0.962 x ; r=0.998 n=75$ ).

- non-lipemic sera

o lipemic sera (not included in calculation of regression line).

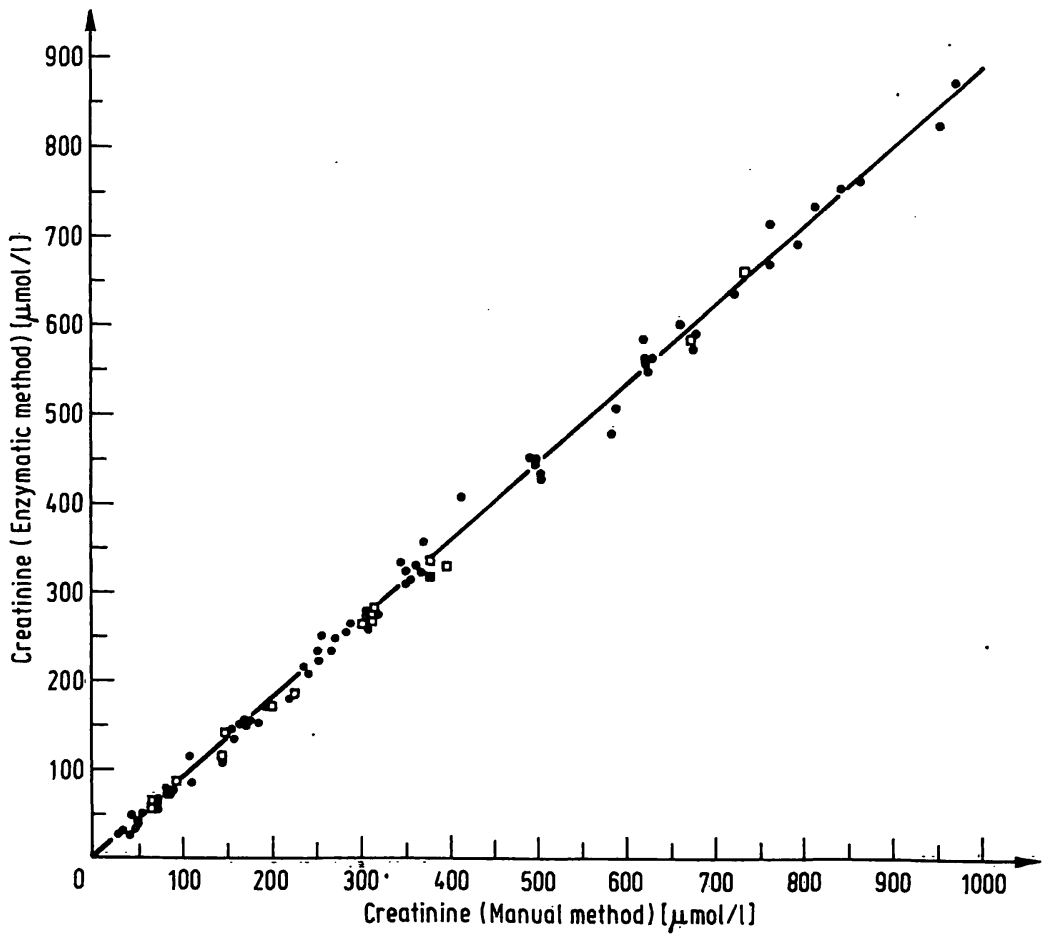

Fig. 3. Split-sample comparison between the enzymatic method ( $y$-axis) and the manual method (x-axis). Straight line represents the regression line (equation: $y=-0.906+0.895 x ; r=0.998 n=73$ ).

- human sera

- commercial control sera (not included in calculation of regression line). 


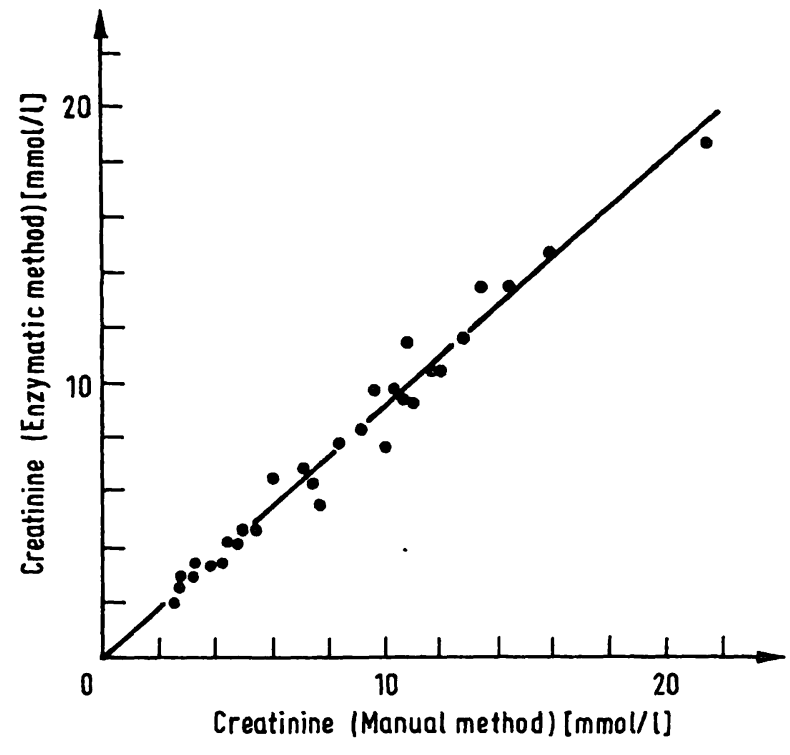

Fig. 4. Split-sample comparison between enzymatic method (yaxis) and manual method ( $x$-axis) for urine samples. Straight line represents the regression line (equation: $\mathrm{y}=0.024+0.906 \mathrm{x} ; \mathrm{r}=0.987 \mathrm{n}=30$ )

Linear regression least squares analysis gave the following regression equations and correlation coefficients:

$$
\begin{aligned}
& \text { serum: y (enzymatic) }=-12.227+0.962 x(\text { SMA 12/60) } \\
& r=0.998 \text { (75 samples). } \\
& \text { serum: } y \text { (enzymatic) }=-0.906+0,895 x \text { (manual) } \\
& r=0.998 \text { ( } 73 \text { samples). } \\
& \text { urine: } y \text { (enzymatic) }=0.024+0.906 x \text { (manual) } \\
& \text { r }=0.987 \text { (30 samples). }
\end{aligned}
$$

\section{Control sera}

The instruction sheet states that occasionally a serum sample can have a very high $\mathrm{NADH}$ consuming activity due to substances in the serum itself (e.g. pyruvate), so that the amount of NADH in the reaction mixture is not adequate. In our experiment series, we noticed this effect twice, once with a human serum and once with a commercial serum (a Technicon SMA 12/60 calibration serum). In this last serum, the measured creatinine concentration was virtually zerô (calibration value: $430 \mu \mathrm{mol} / 1$ ). When we monitored the absorbance of the serum blank during the incubation time, we found an absorbance decrease, which was equivalent to the total amount of $\mathrm{NADH}$ in the reaction mixture, so all available NADH was consumed by substances in the serum itself. To check if pyruvate was responsible for this effect, we determined the pyruvate concentration in the Technicon serum with a Boehringer test kit (Test Combination Pyruvate, cat. no. 124982). The concentration we found was $92 \mu \mathrm{mol} / 1$, which is higher than the normal range given in the instruction sheet (41-67 $\mu \mathrm{mol} / \mathrm{l})$. However, this amount cannot possibly cause the absorbance decrease we observed. In order to investigate whether this effect also applied to other commercial control and calibration sera,
Tab. 5. Specifications of the control sera tested.

\begin{tabular}{lcl}
\hline Name & Lot no. & Manufacturer \\
\hline Versatol & 0164024 General Diagnostics \\
Versatol A & 2262043 General Diagnostics \\
Versatol Pediatric & 4 B 392 General Diagnostics \\
Versatol Calibrate level 1 & 1438045 General Diagnostics \\
Versatol Calibrate level 3 & 1438045 General Diagnostics \\
Versatol Calibrate level 3 & 1438045 General Diagnostics \\
Precinorm S & 813 Boehringer Mannheim \\
Precipath S & 705 Boehringer Mannheim \\
Wellcomtrol 2 & K 4364 Wellcome \\
Wellcomtrol 3 & K 4175 Wellcome \\
RIV A & 70510 National Institute of Public \\
& & Health \\
RIV B & 61123 National Institute of Public \\
& Health \\
Labtrol E & LT-52 Dade \\
Labtrol E & LT-56 H Dade \\
Monitrol II E & PTD-51 A Dade \\
Autonorm & 210 Nyegaard \\
\hline
\end{tabular}

we checked 16 different commercial sera from several manufacturers, with the enzymatic and the manual method. We did not notice the effect in any of these sera. Table 5 specifies the commercial sera we used. The concentration values we measured with both methods are represented in figure 3.

\section{Discussion}

In this report, we have evaluated a new diagnostic kit for the enzymatic determination of creatinine. The method was found to be linear up to $1000 \mu \mathrm{mol} / 1$, tested with aqueous standards. As we already mentioned, the upper limit may not be that high in serum, due to the NADH consumption by substances in the serum itself. Mean analytic recovery was $98 \%$, which agrees well with the results of Szasz \& Börner (5) and Wahlefeld et al. (4). The results of our precision studies also agree with those of the aforementioned authors. Both the enzymatic method and the manual method had comparable precisions, whereas the SMA $12 / 60$ showed a slightly better precision. The coefficients of variation we found compare favourably with the value which is presented as a goal for analytical performance by the College of American Pathologists in the work of Gilbert (12), i.e. a coefficient of variation of $6.7 \%$ at $132 \mu \mathrm{mol} / 1$.

Bilirubin did not interfere with the reaction, even in very high concentrations (up to $490 \mu \mathrm{mol} / \mathrm{l}$ ). Hemoglobin in concentrations above $240 \mu \mathrm{mol} / 1$ lowered the measured creatinine values. Possibly other components from the red cells are responsible for this effect too. Serum hemoglobin concentrations above $240 \mu \mathrm{mol} / 1$ are rare, but may sometimes be found in pediatric samples (13).

With the exception of potassium oxalate, which seems to inhibit the reaction, all anticoagulants we tested did not interfere with the test method. Furthermore, according 
to the Test Report from Boehringer Mannheim (14), the method is not disturbed by a number of common drugs.

Lipemic samples, which are represented in figure 2, do not appear to behave differently from non-lipemic sera. If possible, we feel that dilution should be avoided because of the possibility that the diluted serum sample will have a very low creatinine concentration, which cannot be measured with great precision.

Commonly available control sera can be used for quality control purposes, although we feel that care should be taken because of our experience with the Technicon serum.

Correlation of the enzymatic method with both of the other methods was good. Our enzymatic values were consistently lower than the values we obtained with either the manual or the SMA $12 / 60$ method, but we did not find a $20-25 \%$ difference, as is reported by Szasz \& Börner (5). We have not yet studied the possible causes of these differences.

Another important aspect of the test kit is its price. The reagent price for one single enzymatic test is very high, when compared to the reagent price for one single manual or SMA $12 / 60$ test, which is virtually negligible. However, with the manual method not more than 3040 tests could be performed within 3 hours, whereas with the enzymatic test 60 tests could be performed in 1.8 hours. When a price for one test (i.e. reagent cost + personnel cost) is calculated on the basis of these facts, both the manual and the enzymatic method are equally expensive. Both methods are of course more expensive than the SMA 12/60 method (about 4 times).

Summarizing, we feel that the enzymatic method is a very valuable method, which is very specific for creatinine, and virtually insensitive to the interfering factors we tested. In its present form, the method is not readily adaptable to fully automated systems, but no doubt automated versions will be developed.

\section{Acknowledgements}

We want to thank Miss $H$. Roetering for her skilfull help in performing the determinations with the manual method.

\section{References}

1. Jaffe, M. (1896), Z. Physiol. Chem. 10, 391.

2. Young, D. S., Pestanen, L. C. \& Gibberman, V. (1975), Clin. Chem. 21, $286 \mathrm{D}-288 \mathrm{D}$.

3. Daugherty, N. A., Hammond, K. B. \& Osberg, I. M. (1978), Clin. Chem. 24, 292-293.

4. Wahlefeld, A. W., Herz, G. \& Bergmeyer, H. U. (1972), Scand. J. Clin. Lab. Invest. 29, suppl. 126, abstr. 30.1.

5. Szasz, G. \& Börner, U. (1977), Clin. Chem. 23, 1172.

6. Rand, R. N. (1969), Clin. Chem. 15, 839-863.

7. Dybkaer, R. \& Hertz, H. (1979), Scand. J. Clin. Lab. Invest. $25,151-160$.

8. Van Assendelft, O. W. (1970), Spectrophotometry of haemoglobin derivatives, Van Gorkum, Assen.

9. Crosby, W. H. \& Furth, W. H. (1956), Blood 11, 380-383.

10. IJpma, S. T., Jongkind, C: J. \& Leijnse, B. (1979), J. Clin. Chem. Clin. Biochem. 17, 331-336.

11. Knoll, E. \& Wisser, H. (1973), Z. Klin. Chem. Klin. Biochem. $11,411-414$.

12. Gilbert, R. K. (1975), Am. J. Clin. Pathol. 63, 960-973.

13. Blijenberg, B. G., Brouwer, H. J. and Leijnse, B. (1978), J. Clin. Chem. Clin. Biochem. 16, 425-428.

14. Test Report "Creatinin Enzymatisch", Boehringer Mannheim GmbH, (1978).
Drs. A. Lanser

Acad. Ziekenhuis Rotterdam - Dijkzigt

Dr. Molewaterplein 40

NL-3015 GD Rotterdam 